\title{
Diplomás kisgyermeknevelők szakmai közérzete és jövőképe
}

\author{
Bencsikné Molnár Réka ${ }^{1}$ és Orbán Dóra ${ }^{2}$ \\ ${ }^{1}$ Újbudai Bölcsődei Intézmények, \\ Eötvös Loránd Tudományegyetem Pedagógiai és Pszichológiai Kar \\ Neveléstudományi Doktori Iskola \\ ${ }^{2}$ Újbudai Bölcsődei Intézmények
}

\begin{abstract}
Absztrakt
Jelen tanulmány a diplomás kisgyermeknevelők szakmai közérzetéről szól, és arra tesz kísérletet, hogy értelmezze azokat a perspektívákat, amelyeket a kisgyermeknevelők a szakmai jövőjükkel kapcsolatban látnak. Ehhez szükséges volt megismernünk az eddigi szakmai életutakat, kitekintve a pályaválasztás motívumaira, a csecsemő- és kisgyermeknevelő képzés élményeire és a bölcsődei intézményrendszer munkakörülményeire. A mintánkban 15 diplomás, az Újbudai Bölcsődei Intézményekben dolgozó kisgyermeknevelö szerepel, akik közül 10 fő OKJ-s végzettséggel is rendelkezik. Ennek következtében kutatásunknak nem várt hozadéka, hogy megvilágításba kerültek a két képzési szint sajátosságai is. Kutatásunkban az egyéni írásbeli kikérdezés módszerét és a félig strukturált interjút kombináltuk. A félig strukturált interjúk elemzése az Atlas.ti tartalomelemző szoftver segítségével valósult meg, adatfeldolgozási módszerünk a megalapozott elméleten alapul. Elemzésünk e módszer elveit követi, az adatok elemzése - az induktív kategóriaalkotás - Glaser (1992) elemzési stratégiáján alapszik. Az eredményekből kirajzolódó mintázatok rámutatnak azokra a feltételekre, amelyek hosszú távon motiváltan, örömmel a pályán tarthatják a kisgyermeknevelőket, biztosítva a jó szakmai közérzetet. Magas szintű elhivatottságot tükröz, hogy az intézményünkben dolgozó megkérdezett kisgyermeknevelők mindegyike a szakmához kapcsolódó konkrét továbbtanulási, tanulási és jó néhányan konkrét szakmai jövőképpel rendelkeznek. Eredményeink nemcsak a bölcsődei szakterületnek, valamint a szak fejlesztésével foglalkozó szakembereknek szolgálhatnak fontos ismeretekkel, hanem a szülők számára is megvilágításba kerülhet a csecsemő- és kisgyermeknevelő szakma sokszínüsége.
\end{abstract}

Kulcsszavak: bölcsőde, kisgyermeknevelők szakmai közérzete, jövőkép, megalapozott elmélet, kvalitatív tartalomelemzés

\section{Bevezetés}

Az elmúlt években hazánkban is előtérbe kerültek a kora gyermekkori nevelés intézményeinek müködésére és szakmai gyakorlatára irányuló fejlesztések. Kutatásunk szempontjából a legfontosabb az országos bölcsődei férőhelyeket 
érintő bölcsődefejlesztési program, hiszen a bölcsődei férőhelyek bővítése a szakemberigényt is növeli. A férőhelyek növelése a magyar bölcsődei rendszer fejlesztése és a családok megsegítése szempontjából kulcsfontosságú, ugyanannyira, mint a bölcsődei szakemberképzést érintő változások és folyamatos fejlesztések. Az évtizedeket felölelő kisgyermeknevelő képzés fejlődéstörténetének mérföldköve, hogy hazánkban 2009-től folyik főiskolai szinten kisgyermeknevelő képzés, amely mellett megmaradt a felsőfokú szakképzés, azaz a szakemberképzést két képzési szint együttélése jellemzi. Ez a kettőség számos kérdést felvet a szakma szempontjából, amelyet Podráczky Judit (2020) tanulmányában részletesen kifejt. Tanulmánya számunkra abból a szempontból is érdekes, hogy egyrészt rámutat arra, hogy „újszerű a diplomás kisgyermeknevelő ideája”, másrészt részletesen felvázolja, miért szükséges és fontos a magasabb szintű szakképzettség. Kitér azokra a lépésekre és feladatokra, amelyek a szakemberképzés színvonalának emelésére irányulnak, ezek magukban foglalják a végzettségi szint növelését is.

Tapasztalataink alapján elmondható, hogy a diplomás kisgyermeknevelők körében egyre több a pályaelhagyó, emellett az elmúlt öt évben a csecsemő- és kisgyermeknevelő BA-szakra jelentkezők számát figyelve a statisztikák is csökkenő tendenciát mutatnak. Az 1. ábra a csecsemő és kisgyermeknevelő BA szakra jelentkezők számát összesítve országos szinten mutatja a BA képzés bevezetésének kezdetétől fogva, feltüntetve a szakot első helyen megjelölő felvételizők létszámát. Látható, hogy 2016-ban a kezdeti számokhoz képest megemelkedett a csecsemő-és kisgyermeknevelő BA szakra jelentkezők száma, ez annak köszönhető, hogy Balogh Zoltán 2015 áprilisában bejelentette, hogy 2016tól a kormány kiterjeszti a felsőfokú végzettségű bölcsődei kisgyermeknevelőkre a pedagógus életpályát ${ }^{1}$. A rendelet hatására az egyetemi képzés anyagilag is vonzóvá vált a bölcsődékben dolgozó más végzettséggel rendelkező kisgyermeknevelők számára is. A mintánkban szereplő kisgyermeknevelők 73\%-a az ELTE Tanító- és Óvóképző Kar csecsemő- és kisgyermeknevelő BA-szakán végzett, ezért kíváncsiak voltunk arra, hogy az ELTE-t milyen mértékben érintik a felvételi létszámok változása. A 2. ábrán látható, hogy míg 2016-ban 1. helyen 777 fó jelölte meg az ELTE Tanító-és Óvóképző Kar csecsemő- és kisgyermeknevelő BA-szakot, addig ez a szám 2020-ban drasztikusan 81 före csökkent ${ }^{2}$. Itt fontos megemlíteni, hogy ugyan a 2020-as felvételitől lett volna kötelező a középfokú nyelvvizsga és az egy emelt szintü érettségi vizsga teljesítése, a kormányrendelet végül elengedte a középfokú nyelvvizsga-követelményt, az emelt szintü érettségi teljesítésére vonatkozó követelmény azonban megmaradt ${ }^{3}$.

\footnotetext{
${ }^{1}$ 326/2013. (VIII. 30.) Korm. rendelet a pedagógusok előmeneteli rendszeréről és a közalkalmazottak jogállásáról szóló 1992. évi XXXIII. törvény köznevelési intézményekben történő végrehajtásáról

${ }^{2}$ A felvi.hu elmúlt évek statisztikai adatai. Az adatok kizárólag a szeptemberben induló képzésekre vonatkoznak, beleértve a nappali és a levelező tagozatot (államilag támogatott és költségtérítéses forma). Az adatok nem tartalmazzák a pótfelvételizők számát.

${ }^{3}$ A felsőoktatási felvételi eljárásról szóló 423/2012. (XII. 29.) korm. rendelet
} 


\section{1. ábra}

A csecsemö- és kisgyermeknevelö BA-szakra jelentkezők száma országos szinten

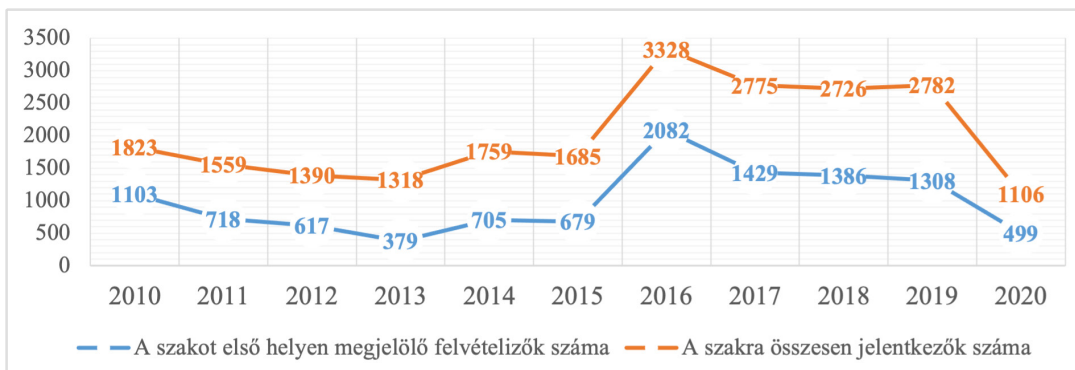

\section{2. ábra}

A csecsemö- és kisgyermeknevelö BA-szakot megjelölö felvételizök száma az ELTE Tanitó- és Óvóképző Karon (saját szerkesztés)

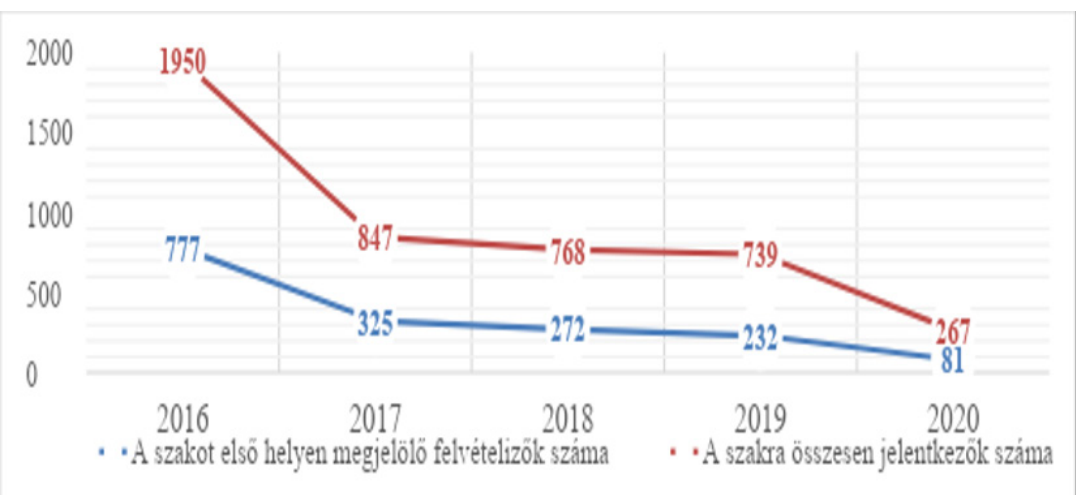

Magyarországon a bölcsődei intézményekben többféle szakképesítés$\operatorname{sel}^{4}$ helyezkedhetnek el a kisgyermeknevelők. Az Újbudai Bölcsődei Intézményekben 143 kisgyermeknevelő dolgozik a gyermekcsoportokban, ebből mindössze 29 kisgyermeknevelő rendelkezik csecsemö- és kisgyermeknevelő BA-diplomával, ami a kilenc tagbölcsődére vetítve kevésnek számít.

\footnotetext{
${ }^{4}$ Csecsemő- és kisgyermeknevelő (BA), bölcsődei szakgondozó (OKJ), csecsemő- és kisgyermekgondozó (OKJ), csecsemő- és kisgyermeknevelö-gondozó (OKJ), csecsemő- és gyermeknevelő-gondozó (OKJ), kisgyermekgondozó, -nevelő (OKJ), csecsemő- és kisgyermeknevelő asszisztens (FOKSZ), csecsemő- és gyermekgondozó (OKJ); vagy ezen képesítések valamelyikével rendelkező: védőnő, pedagógus, felsőfokú szociális alapvégzettségü személy vagy gyógypedagógiai asszisztens (OKJ) [kizárólag csecsemő- és gyermekgondozó (OKJ) képesítéssel rendelkező személy esetén] (6/2016. (III. 24.) EMMI rendelet a személyes gondoskodást nyújtó gyermekjóléti, gyermekvédelmi intézmények, valamint személyek szakmai feladatairól és működésük feltételeiről szóló 15/1998. (IV. 30.) NM rendelet módosításáról)
} 
A kisgyermekekkel való foglalkozás a bölcsődében professzionális tudást igényel, a kisgyermeknevelők a gondozás mellett minden fejlődési területet érintő komplex szakmai munkát folytatnak: nevelnek, fejlesztenek. Ennek okán a vezetői prioritások közé tartozik egyrészt a középfokú végzettséggel és a felsőfokú szakképesítéssel rendelkező munkavállalók ösztönzése arra, hogy jelentkezzenek a csecsemő- és kisgyermeknevelő BA-szakra, másrészt a csecsemő- és kisgyermeknevelő BA-diplomával rendelkező munkavállalók megtartása. Ehhez ismerni kell a munkavállaló kisgyermeknevelők szakmai közérzetét és jövőképét.

Jelen tanulmány alapjául szolgáló kutatás az Újbudai Bölcsődei Intézmények intézményvezetője, Unger Katalin megbízásából készült, amely kizárólag az Újbudai Bölcsődei Intézményekben dolgozó, csecsemő- és kisgyermeknevelő BA-diplomával rendelkező kisgyermeknevelők szakmai közérzetére és jövőképére terjed ki. Kutatásunk célja egyrészt az Újbudai Bölcsődei Intézményekben dolgozó csecsemő- és kisgyermeknevelő BA-diplomával rendelkező kisgyermeknevelők szakmai közérzetének, jövőképének megismerése, a szakmára való távolabbi rátekintés, másrészt a kisgyermeknevelöket közvetlenül megszólítva foglalkozni a szakmai önismeretükkel, a kisgyermeknevelői szakma problematikájával, kérdéseivel.

A kutatás tervezésénél fontos szempont volt, hogy az egyéni interjúknak olyan önismereti-szakmai hozadéka lehet, amely sokat adhat a kisgyermeknevelők számára is.

Jelen tanulmány arra tesz kísérletet, hogy megismerje a kisgyermeknevelők szakmai közérzetét és értelmezze azokat a perspektívákat, amelyeket a kisgyermeknevelők a szakmai jövőjükkel kapcsolatosan látnak. Ehhez azonban szükséges megismernünk az eddigi szakmai életutakat, kitekintve a pályaválasztás motívumaira, a csecsemő-és kisgyermeknevelő képzés élményeire és a bölcsődei intézményrendszer munkakörülményeire.

\section{Minta, adatfelvétel}

Az alapsokaságot a XI. kerületi Újbudai Bölcsődei Intézmények kilenc tagbölcsődéjében dolgozó csecsemő- és kisgyermeknevelő BA-diplomával rendelkező kisgyermeknevelők száma jelenti, azaz 29 fö.

A kisgyermeknevelőket a kutatás megkezdése előtt egy e-mailben részletesen tájékoztattuk a kutatás céljáról és menetéről. A munkavállalók az adataik kezeléséhez adatkezelési nyilatkozatban járultak hozzá. A kutatásban való részvétel önkéntes jellegű volt, a mintába az összes jelentkező bekerült, azaz kutatásunkban összesen 15 kisgyermeknevelő vett részt, akik közül 10 fő csecsemő- és kisgyermeknevelő-gondozó OKJ-képesítéssel is rendelkezik.

A 3. és 4. ábra szemlélteti, hogy a kutatásunkban részt vevő alanyok többsége olyan fiatal, aki pár éve van a pedagóguspályán. A kisgyermeknevelők életkorát tekintve a legtöbben 25 és 30 életév közöttiek. 
3. ábra

A kisgyermeknevelők életkora

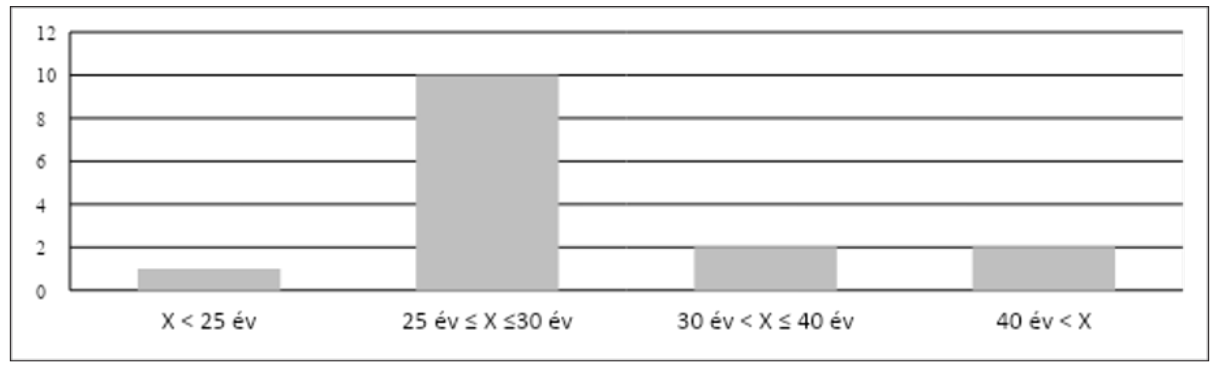

4. ábra

A pedagóguspályán eltöltött évek száma

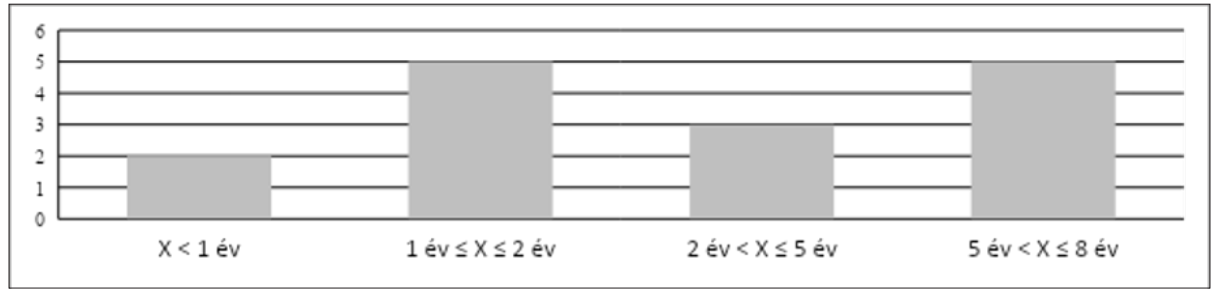

A kisgyermeknevelők kétharmada gimnáziumban tanult, akik pedig szakközépiskolába jártak, azok közül többen ott végezték el a kisgyermekgondozó-nevelő képzést. (5. ábra)

\section{5. ábra}

Képzőintézmények típusának megoszlása, ahol a kisgyermeknevelók tanultak a föiskolai képzés elött

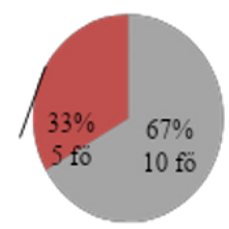

A járványügyi veszélyhelyzetre való tekintettel az adatgyűjtés online módon zajlott. Az online kérdőívet minden jelentkező e-mailben kapta meg. Az egyéni interjúk szintén online módon zajlottak előre egyeztetett időpontban. Az interjúk rögzítése diktafonnal történt, a hanganyagok szöveges átírásra, azt követően pedig megsemmisítésre kerültek. 


\section{Kutatási paradigma}

Kutatásunk a kevert módszertanon alapszik. A kevert módszer formái közül a beágyazott felépítést alkalmaztuk, amely során kvalitatív és kvantitatív adatokat is gyüjtöttünk egy alapjaiban véve kvalitatív kutatás keretein belül. Ennél a felépítésnél a másodlagos módszertannak, jelen kutatásban a kvantitatív módszernek kiegészítő szerepe van. Eredményeinek értelmezhetősége a kvalitatív módszertannal szerzett adathalmazba ágyazódva történik (Király et al., 2014, p. 101). A két módszer keverésének a fö területe a tervezési szint volt, azaz a kvantitatív és a kvalitatív szakasz interakciójának szintjét az interaktivitás jellemzi. A kérdőívezés és az egyéni félig strukturált interjúzás párhuzamosan zajlott (a módszerről lásd Király et al., 2014).

\section{Kutatási kérdések}

Kutatásunkban az alábbi kérdésekre kerestük a válaszokat:

1. Milyen tapasztalatokkal rendelkeznek, és hogyan vélekednek a BA-képzéssel kapcsolatosan a kisgyermeknevelők?

2. Milyen szakmai közérzettel rendelkeznek a kisgyermeknevelők?

3. Mik azok a feltételek, amelyek hosszú távon motiváltan, örömmel a pályán tarthatják a kisgyermeknevelőket?

4. Milyen perspektívákat látnak szakmai jövőjükkel kapcsolatosan?

\section{A kutatás módszere és eszköze}

Kutatásunkban két adatgyűjtési módszert kombináltunk: az egyéni írásbeli kikérdezés módszerét és a félig strukturált interjút. A kutatásban részt vevő kisgyermeknevelők az egyéni interjú mellett egy online kérdőívet töltöttek ki. Az interjúkészítés folyamata alatt, amely másfél hónapot vett igénybe, folyamatosan lehetőség volt a kérdőív kitöltésére. A kérdőív felépítése az alábbi 1. táblázatban látható.

\section{1. táblázat}

\section{A kutatás kérdőivének felépitése}

\begin{tabular}{|l|ll|}
\hline $\begin{array}{l}\text { Egyértelmű, rövid } \\
\text { válaszokat inspiráló } \\
\text { ténykérdések }\end{array}$ & \begin{tabular}{l} 
Hány éves vagy? \\
- $\begin{array}{l}\text { Hol laksz? } \\
\text { Hol van a tartózkodási helyed? }\end{array}$ \\
\hline $\begin{array}{l}\text { Feleletválasztást } \\
\text { igénylő kérdések éve vagy a pedagóguspályán? }\end{array}$
\end{tabular} & $\begin{array}{l}\text { Az alábbiak közül kérlek, jelöld be, mely intézménytípusban } \\
\text { tanultál. (Gimnázium/ Szakközépiskola) } \\
\text { Édesanyád iskolai végzettsége. (Legfeljebb } 8 \text { általános/ Szak- } \\
\text { munkás/ Érettségi/ Felsőfokú) } \\
\text { Édesapád iskolai végzettsége. (Legfeljebb } 8 \text { általános/ Szak- } \\
\text { munkás/ Érettségi/ Felsőfokú) }\end{array}$ \\
\hline
\end{tabular}




\begin{tabular}{|l|l|}
\hline $\begin{array}{l}\text { Terjedelmesebb kifej- } \\
\text { tést igénylő kérdések }\end{array}$ & $\begin{array}{l}\text { Amennyiben csecsemő-és kisgyermeknevelő BA-szakot } \\
\text { végeztél, jelöltél-e meg más felsőoktatási szakot a csecsemő- } \\
\text { és kisgyermeknevelö BA-szak mellett? Ha igen, mely szakot, } \\
\text { és azt hányadikként jelölted meg? } \\
\text { A csecsemő-és kisgyermeknevelö BA-szakot munka mellett } \\
\text { végezted el? Ha igen, milyen munkát végeztél közben? } \\
\text { Az Újbudai Bölcsődei Intézmények elött voltak-e korábbi } \\
\text { munkahelyeid? Ha igen, melyek azok? } \\
\text { Van a családodban pedagógus? Ha igen, hány pedagógus, és } \\
\text { ök milyen korosztállyal foglalkoznak/foglalkoztak? }\end{array}$ \\
\hline
\end{tabular}

A félig strukturált interjú felépítése öt részből állt, amelyet a 2. táblázatban szemléltetünk:

\section{2. táblázat}

\section{A félig strukturált interjú felépitése}

\begin{tabular}{|l|ll|}
\hline \multicolumn{1}{|c|}{ Kérdéscsoportok } & \multicolumn{1}{c|}{ A kérdéscsoportokhoz tartozó kérdések } \\
\hline $\begin{array}{l}\text { A pályaválasztásra } \\
\text { irányuló kérdések }\end{array}$ & - & Miért ezt a pályát választottad? \\
\hline $\begin{array}{l}\text { A képzéssel kapcsola- } \\
\text { tos kérdések }\end{array}$ & $\begin{array}{l}\text { Milyen volt a képzés? } \\
\text { - }\end{array}$ & $\begin{array}{l}\text { Milyen élményeid voltak a képzéssel kapcsolatosan? } \\
\text { Mit adott az egyetem? }\end{array}$ \\
\hline $\begin{array}{l}\text { A szakmai közérzetre } \\
\text { irányuló kérdések }\end{array}$ & \begin{tabular}{l} 
Milyen a jelenlegi közérzeted ebben a hivatásban? \\
- $\begin{array}{l}\text { Milyen árnyoldalai vannak ennek a pályának? } \\
\text { A munkakörülményeket tekintve milyen változások szüksé- } \\
\text { gesek? }\end{array}$ \\
\hline $\begin{array}{l}\text { A hivatással kapcsola- } \\
\text { tos kérdések }\end{array}$
\end{tabular} & $\begin{array}{l}\text { Honnan kapsz szakmai segítséget, támogatást? } \\
\text { Aki viszonylag hosszú ideig tartósan a pályán tud maradni, } \\
\text { mert jól érzi magát, annak mi a záloga? }\end{array}$ \\
\hline $\begin{array}{l}\text { Mit szeretsz a hivatásodban? } \\
\text { - }\end{array}$ & $\begin{array}{l}\text { Felmerült-e benned a pályaelhagyás gondolata? } \\
\text { Mit lehetne ezért a szakmáért tenni? }\end{array}$ \\
\hline kérdések & $\begin{array}{l}\text { Milyen az ideális pedagógus pálya? } \\
\text { Kinek ajánlanád ezt a pályát? }\end{array}$ \\
\hline
\end{tabular}




\section{Az eredmények elemzésének módszertana: a megalapozott elmélet}

A megalapozott elmélet kifejezés két amerikai szociológus, Barney G. Glaser és Anselm L. Strauss 1967-ben megjelenő - A megalapozott elmélet felfedezése: stratégiák a kvalitatív kutatáshoz (The Discovery of Grounded Theory: Strategies for Qualitative Research, röviden: Discovery) - könyvükben jelent meg (bővebben Kucsera, 2008). Glaser és Strauss módszere egy újfajta szemlélteváltást eredményezett a társadalomtudományi elméletalkotás és az empirikus adatok vonatkozásában. Az adatok fogalmi szintre történő növekedéséből születik a releváns elmélet, amelyhez induktív és abduktív logikájú lépések vezetnek (Sallay \& Martos, 2018). Az 1970-es években különváltak Glaser és Strauss útjai, felfogásbeli különbségeik az adatok kódolásának eltérő koncepciói mentén érhetők tetten (Kucsera, 2008).

A félig strukturált interjúk elemzése az Atlas.ti tartalomelemző szoftver segítségével valósult meg, amely a megalapozott elméleten - grounded theory-n - alapul. Elemzésünk e módszer elveit követi, az adatok elemzése az induktív kategóriaalkotás Glaser (1992) elemzési stratégiáján alapszik. Glaser elemzési módszerének a sajátosságai a következők:

- Előnyben részesíti a kreativitást.

- Nyitott az előre nem látható, újszerü interpretációkra (Mitev, 2015, p. 102).

- Tisztán induktív módszer. A kategóriák az empirikus anyagból fejlődnek ki.

- Az elemzési stratégia az adatok folyamatos összehasonlításán alapul.

- Szubsztantív és elméleti kódokat használ. A szubsztantív kódok spontán, nyitott kódokat foglalnak magukba, míg az elméleti kódok magasabb szinten állnak, elvontabbak és a szubsztantív kódokból épülnek fel, ezáltal körvonalazódik az elmélet.

- A kódolási eljárás során nyitott és szelektív kódokról beszélhetünk. A nyílt kódolással teljesen szétszedjük az adatot (jelen esetben az interjút). A szelektív kódolás során a nyitott kódokban egyre jobban kivehető kulcskategóriákra összpontosítunk, minden mást ennek rendelünk alá, ezt akarjuk telíteni (Kucsera, 2008; Mitev, 2012; Mitev, 2015; Sántha, 2020).

\section{A kutatás minőségi kritériuma}

A kutatás megbízhatóságának eléréséhez a következő eljárásokat alkalmaztuk:

Az adatok szöveghü rögzitése (Szokolszky, 2004). Az interjúkat diktafonnal rögzítettük, majd kutatóként saját magunk gépeltük be, ezzel már gyakorlatilag megkezdtük az elemzést. Jegyzetelés nélkül mind a 15 szöveget meghallgattuk, képet kapva a szöveg teljességéről, tartalmáról. A már begépelt szöveget újra meghallgattuk, ahol kellett a szöveget korrigáltuk és az így elkészült szöveg már technikailag is készen állt az elemzésre (Szabolcs, 2001). 
A kutatók közötti egyetértés ellenörzése (Szokolszky, 2004). A kódolási folyamat megbízhatóságának ellenőrzésére interkódolást alkalmaztunk, azaz, mindketten egymástól függetlenül kódoltuk ugyanazt a dokumentumot, majd a kapott kategóriákat összehasonlítottuk. A kódolási folyamat megbízhatósága kizárólag a szubsztantív kódolás során meghatározott kategóriákra vonatkoztatható, ugyanis a többi fázisban történő kódolásnál a kutató kreativitása fontos szerephez jut, amelynek következtében szubjektív hatások jelenhetnek meg (Sántha, 2012).

A kutatás dokumentálása A kutatás minden lépését dokumentáltuk, a háttérinformációkat rögzítettük (Szokolszky, 2004).

\section{Az eredmények bemutatása}

\section{A kisgyermeknevelök csecsemö- és kisgyermeknevelö BA-képzésen szerzett tapasztalatai}

A mintánkban szereplő kisgyermeknevelők többsége az ELTE Tanító-és Óvóképző Karán szerzett csecsemő- és kisgyermeknevelő végzettséget. (lásd 6. ábra)

\section{6. ábra}

Képzőintézmények, ahol a kisgyermeknevelök tanultak

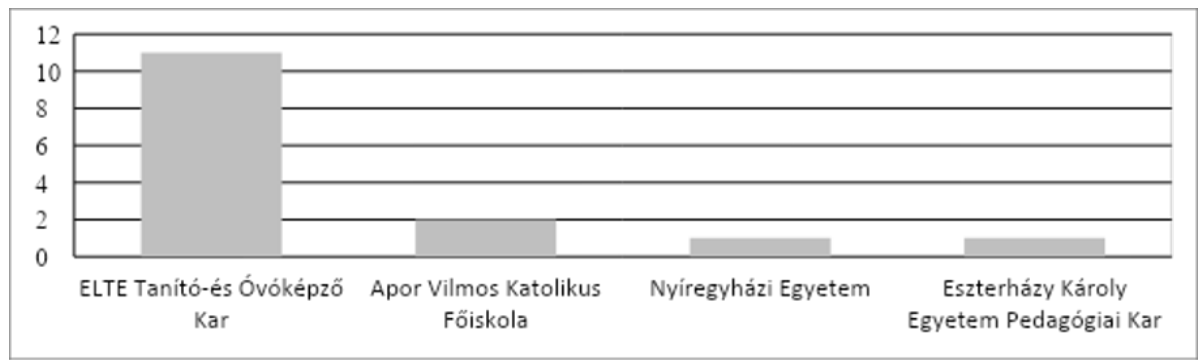

Megkérdeztük a kisgyermeknevelőket, hogy a csecsemő- és kisgyermeknevelő szak mellett jelöltek-e meg más felsőoktatási szakot. A 15 főből 5 kisgyermeknevelő jelölt meg egyéb szakot, ebből 3 fő nem a csecsemő- és kisgyermeknevelő szakot jelölte meg elsőnek. Az egyéb felsőoktatási szakok a következők voltak a csecsemő- és kisgyermeknevelők körében: óvodapedagógia, gyógypedagógia, biológia. A szakot 10 fö munka mellett végezte el, ebből 5 fö már kisgyermeknevelőként dolgozott valamely bölcsődében. A 15 főből 7 főnek található a családjában pedagógus végzettséggel rendelkező személy, ez meghatározó tényező volt pályaválasztásuk során.

A megkérdezett kisgyermeknevelők nagy része (10 fö) az OKJ-s képzés elvégzése után tanult tovább. Ennek következtében kutatásunknak nem várt 
hozadéka, hogy megvilágításba kerültek a két képzési szint sajátosságai is. Többen megemlítették az OKJ-s képzésen oktató tanáraikat (aktív bölcsődei vezetők), akik saját szakmai személyiségükkel és javaslataikkal a továbbtanulás irányába motiválták a hallgatókat.

Az OKJ-s képzés volt számukra az első találkozás a szaktudással, a szakmai ismeretekkel, a bölcsőde világával. Ez a találkozás úgy tűnik, minden interjúalanyunk számára sikeres volt. Az OKJ-s képzésen, a gyakorlatorientált haladás és a tudást átadó tanáraikkal való együttműködés során vált egyre érdekesebbé, vonzóbbá a szakma, sok pozitív élményről számoltak be a résztvevők. Testközelbe kerülhettek a szakmával és a szakma gyakorlóival, sok élménnyel és megerősödött motivációval haladtak tovább. A kisgyermeknevelők iskolaválasztása sikeres volt, akikkel beszéltünk, elmondásuk szerint, a helyükön érezték magukat a képzési folyamatok elejétől fogva, egyikük sem gondolkodott a pálya elhagyásán.

Úgy érzik, a felsőoktatás az OKJ-s képzéshez képest kevésbé gyakorlatorientált, nem az OKJ „folytatása”, az intenzív gyakorlati tapasztalás megtorpan, ezt majdnem mindannyian említették csalódásként: „A gyakorlati tudás hiányzik a BA-képzésböl.”; „A föiskolán a gyakorlat nagyon kevés volt.”; „Én szerettem volna, ha a gyakorlatból lenne több."; „Nem érzem azt, hogy gyakorlatban sokat adott volna számomra a BA-képzés, az alapokat inkább az OKJ-s képzés adta. A BA-képzésen is nagyon jól éreztem magam, meg voltam elégedve az ELTE oktatásának minöségével.;; „Az OKJ-s képzésen sokkal több volt a gyakorlat.; „A BA-képzésen sokkal kevesebb a gyakorlat.; „Sokkal több gyakorlatot kellene beépiteni a BA-képzésbe.”

A BA-képzésen a gyakorlat élményei is mások voltak. Úgy érezték kevésbé vehettek részt a csoport életében, sokáig csupán mint megfigyelők voltak jelen. A négyhetes összefüggő terepgyakorlaton teljesedhettek ki a kisgyermeknevelők, úgy gondolják, több ilyenre lenne szükség a képzés alatt.

Azok a kisgyermeknevelők is, akik nem végezték el az OKJ-s képzést, kevésnek ítélték a gyakorlatot a BA-képzésen.

A megkérdezett kisgyermeknevelők a BA-képzés minőségi, gazdag ismeretanyag átadását emelték ki: „Igazi ismeretanyagot a föiskolán kap az ember."; "Ami nagyon tetszett a képzésen, hogy a tanárok partnerként kezeltek. Az elméleti oktatás is jó volt.”; „A BA-képzés elméletben sokat adott számomra." Olyan szakirodalmi tájékozottságra tettek szert, amelyet a gyakorlatban is sikeresen alkalmaznak: "Irodalomban olyan jó könyveket ajánlottak, ezért nagyon hálás vagyok.”; "Az irodalom szempontjából nagyon sok pluszt kaptam az egyetemtöl."; "A föiskola nagyon sokat adott ismeretben, az irodalmat emelném még ki. Olyan dolgokra hívta fel a figyelmemet, amelyekre eddig nem gondoltam. Ez alapján írtam meg a meséimet."

A BA-képzéssel kapcsolatban a kisgyermeknevelők néhány tárgyat, ismeretkört is megemlítettek, amelyeket hasznosnak éreztek, örömmel tanultak (a tudásátadás módja és a tananyag maga is vonzerővel bírt), illetve a diploma megszerzése után a mindennapok során hasznosítani tudták azokat. 
Ezek a gyermekirodalom, a gyógypedagógia, a pszichológia, az ének-zene és a vizuális neveléshez tartozó tárgyak voltak: „A képzésen az egyik legjobb az volt, hogy megtanultam furulyázni, amit a gyakorlatban tudok alkalmazni.;; „Az ének szempontjából nagyon sok pluszt kaptam az egyetemtöl."; „A pszichológiai oldalt emelném ki, mindig is mélyebben érdeklődtem a pszichológia és a gyógypedagógia iránt, a kutatások iránt, itt az egyetemen több féléven keresztül beleástuk magunkat. A mentálhigiénés órák nagy gyakorlati tudást adtak."; "Az egyetem nagyon sok tapasztalatot adott, az élettel kapcsolatosan is. A pszichológia kiemelkedő tudást adott.”; „Gyermekirodalomból egy széles spektrumot kaptunk. Ez az OKJ-s képzésen nem volt. A kortárs gyermekirodalmat be tudtam emelni a munkámba és ez nagyon jó volt.”; „A gyermekirodalmat, a vizuális neveléssel kapcsolatos órákat nagyon szerettem."

A közismereti jellegű tárgyak tanulását, komoly számonkérését néhányan feleslegesnek tartották, azonban volt, aki kiemelte ezen tárgyak jelentőségét is: „Ami bennem volt, hogy a három év alatt minden tudást magamba szivjak, és úgy voltam vele, hogy mindennek megvan az oka, hogy mit miért tanulunk és ez a háttértudás fontos lesz, segít majd abban, hogy több oldalról lássak egy problémát. Legyenek forrásaim szakmailag, ami után tudok olvasni."

Az interjúkból kirajzolódtak olyan mintázatok is, amelyek a BA-képzés hozadékára irányulnak: „Nekem sokat adott, sokkal többnek érzem magam.”; „A BA-képzés irányt mutatott, merre szeretnék menni. Mindig kell tanulni, tovább fejlödni.”; „Kitartást tanitott nekem a föiskola.”; „Egyébként én élveztem nagyon, átélni az egyetemi közösséget, azt, hogy milyen egyetemre járni."

A két képzési forma eltérő tapasztalatai megragadhatók azon kisgyermeknevelők számára, akik mindkettőt megismerhették, így azok a hiányok is, amelyeket a későbbi gyakorlati munka során kellett bepótolniuk. Hiányolták a kisgyermeknevelői dokumentációval kapcsolatos készségek fejlesztését, vagy akár a dokumentáció elemeinek olyan ismeretét, ami példákon keresztül kerül feldolgozásra. A gyakorlat hiányát mindannyian említették. Elmondásuk szerint az olyan fontos készségek, amelyek a váratlan és változó helyzetekben fontos vázai a kisgyermeknevelők komplex munkájának - kommunikációs készségek, önismeret - szintén hiányosan szerepeltek a tananyagban. A kisgyermeknevelők számára a szülőkkel való együttműködés során átélt kommunikációs helyzetek jelentik a legnagyobb kihívást a jelenlegi mindennapi munka során. Ehhez muníciót a kommunikációs készségfejlesztés és az önismereti munka adhat. Az elméleti ismeretek vagy gyakorlati fogások nem elegendőek a többszörösen összetett helyzetek kezelésére. A kisgyermeknevelői, felsőoktatásból kilépő kör gyakran a fiatalabb korosztályt képviseli, emberismeretben, életismeretben a legjobb szándék és legmagasabb szintű tudás ellenére sem rendelkeznek sok tapasztalattal. Rásegítés nélkül a személyközi helyzetek lehetnek a szakmai elakadások forrásai. A bölcsődén belül történő támogatások hellyel-közzel tudnak ezen segíteni, amennyiben megvalósulnak, de a felsőoktatás képzései lehetnének az első állomásai a téma megismerésének, a személyes kérdéseken való munkának 
még a munka megkezdése előtt. A kisgyermeknevelők szerint a rátermettség vagy alkalmasság kérdései is ebbe a körbe tartoznak, akár az önismereti munka fókuszában is állhatnának, de az egyszerű pszichológiai alkalmassági vizsgálatnak is lenne relevanciája a képzések során. A kisgyermeknevelők említést tettek azokról a társaikról, akik egyénileg nem jól mérték fel a saját terhelhetőségüket, érdeklődésüket, motivációjukat, és mivel ezt a szakmai önismereti folyamatot nem segítette a képzési hely, munkahelyi kudarcok vagy nehéz helyzetek árán kellett saját tapasztalatot szerezniük és így rögtön elhagyták a pályát.

Jelenleg a bölcsődéink többségében olyan kisgyermeknevelők dolgoznak, akik OKJ-s végzettséggel rendelkeznek és még nem kezdték el a felsőfokú képzést, vagy nem is tervezik az elvégzését. Kíváncsiak voltunk, hogy a napi munka során a BA-végzettségü interjúalanyaink meg tudnak-e ragadni a két eltérő képzettségű kisgyermeknevelői csoport között bárminemű különbséget. Az elméleti ismeretek közötti különbségek jelentek meg a beszámolókban, de leginkább az eltérő gyakorlati tudások, készségek térnek el képzésenként egymástól. A munkavállalói elvárásokban a diplomás kisgyermeknevelők számára a portfólió elkészítése és a minősítő vizsga komolyabb próbatétel, mint az OKJ-s kisgyermeknevelők számára előírt gyakornoki vizsga. Ezt többen nehezményezték: „Mi szenvedünk a gyakornoki vizsgával, amit két év után kell letenni, és aki az OKJ-t végezte el, annak semmi a gyakornoki vizsga. Nekem ez egy éven át húzódó dolog és nem egyszerü. Már itt is sokkal több tudást várnak el tölem, mint egy OKJ-stól."

A különbségekkel kapcsolatosan egyöntetű vélemény, hogy nem a végzettség számít, hanem a személyiség és a gyakorlati tudás, legvégső sorban pedig a hatékony együttmüködés.

\section{A hivatásszemélyiség gondozása - a pályán maradás (feltételezett) feltételei}

A következőkben azokra a feltételekre kívánunk rámutatni, amelyek az interjúalanyok szerint hosszú távon, motiváltan, örömmel a pályán tarthatják a kisgyermeknevelőket, és amelyek hozzájárulhatnak a jó szakmai közérzethez. A 7. ábra azokat, az interjúk során kirajzolódó mintázatokat szemlélteti összesítve, amelyek megjelennek mint (feltételezett) feltételek a csecsemőés kisgyermeknevelők pályán maradásához és a jó szakmai közérzet biztosításához. 
7. ábra

A pályán maradás feltételei a kisgyermeknevelők szerint

Feltételek, amelyek hosszútávon, motiváltan a pályán tartják a kisgyermeknevelóket

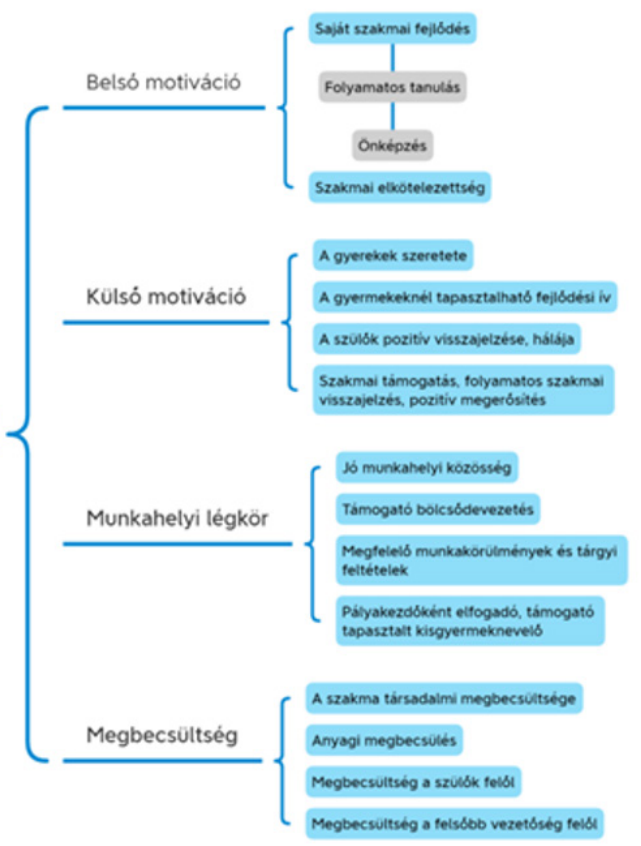

A kutatásunkban szereplő kisgyermeknevelőknek - akik kivétel nélkül motiváltan, célirányosan érkeztek a csecsemő- és kisgyermeknevelő pályára - $a$ folyamatos fejlődés perspektívája, a lineáris haladás „felfelé” a szakmai tudásokban és a szakmai feladatokban fontos motiváló tényezők és a jelenben zajló munkára hatással vannak. Az interjúalanyok számára az energia- és munkabefektetés a szakmai ismeretek megszerzésébe nem egy lezárt folyamat a munkába állással. A kisgyermeknevelők az egyetem, föiskola elvégzésével közel kerülnek a még megszerezhető ismeretekhez, tudományágakhoz, jelenségekhez, konkrét képzésekhez, saját kompetenciakészletük gyarapodik, önértékelésük nő. Az érdeklődés újabb szakmai témák és területek iránt, valamint a további tanulási motiváció minden alanyunknál megjelent: „A saját szakmai fejlődésem miatt is szeretem ezt a munkát csinálni.”; „Folyamatosan fejlödik az egyén és képezi magát mindennap.”; „Mindent szeretnék tudni, jól csinálni, ez hajt legbelül." A tanulási kedv konkrét (anyagi, szervezési) támogatása intézményi, vezetői, szakmai szinten fontos eleme lehet a diplomás kisgyermeknevelők pályán való megtartásának. A kisgyermeknevelők számára a csoportszoba csak akkor tud elég tágas lenni, ha messzire látnak ki belőle, és ha fejlődhetnek a mindennapi munkájuk során, amelyben a nevelő-gondozó munka mind 
a gyermek, mind a kisgyermeknevelő számára perspektívába helyezhető (a gyermek fejlődési útjának kísérése, a családokért így a társadalomért végzett munka, a saját fejlődés élménye). Az itt és most momentumok akkor válhatnak gazdaggá, tartalmassá, ha a kisgyermeknevelő elégedett azzal, ahol van, és amit csinál. Ha tudja, hogy mi az értelme, célja a konkrét cselekvéseinek, hogy hogyan hat ezzel nagyobb rendszerekre. Szélesebb értelmezési keretben látni a napi munka apró történéseit és átélni a jelentőségét minden mozzanatnak örömmel végzet munkához vezet. Ahhoz, hogy az ismeretek ne "pangjanak”, ne maradjanak mozdulatlanok, új ismeretek megszerzése és azok integrálása (kipróbálása, beépítése) szükséges újra és újra.

A visszajelzések jelentősége is ide tartozik. A gyerekek szeretete, mint külső motiváció sokszor felbukkant az interjúk során: „Ami örömet okoz, az arc, mikor látom a visszajelzést a gyerek arcán. Az emberi visszajelzés. Adtál valamit, foglalkoztál vele, ezt úgy vissza tudják adni, hogy az hihetetlen."; „Megtalálod bennük azt az örömet, amire úgy vágyik az ember, az öszinte szeretetet. Jön a gyerek és megölel, pedig te csak egy kisgyermeknevelö vagy."; „A gyerekek szeretete az, ami motivál."; „A gyerekek szeretete tart a pályán. Elvetek magokat, minden hat a gyerekekre.”; "Az tart valakit ezen a pályán, ha meg tudja találni a gyerekek örömében a saját örömét.” A gyermekeknél tapasztalható fejlődési ív szintén motivációs tényezőként jelenik meg a kisgyermeknevelők körében: „A gyerekeknél jó látni a fejlődési ívet, amit én beleteszek, az visszajön.”; „A gyerekek hálája motivál, és a fejlödési iv, amit a gyerekeknél látok."; „Várom a gyerekeknél a fejlödési szintek elérését.”

A szakmai munkával kapcsolatos visszajelzések és a családoktól érkező jelzések szintén nagyon fontosak a kisgyermeknevelők számára. A szakmai visszajelzések szintén támogatják a konkrét feladatokban való fejlődést, de még fontosabb szerepük van az egyén szakmai, szervezeti identitása és végső soron a szakmai közérzet szempontjából: „Fontos, hogy megköszönjék a munkádat, érezd, hogy megbecsülnek. Amikor megcsináltam a gyakornoki vizsgámat, és az intézményvezetö is ott volt és megköszönte a munkámat, én majdnem elsírtam magamat." A visszajelzések, főleg, ha az szakmailag hozzáértő személy, intézményvezető/bölcsődevezető/szaktanácsadó irányából megfelelő minőségben zajlanak (keretezetten, elegendő időt hagyva rájuk, dialógusban, rendszeresen, elvárhatóan), a szakmaiságot, professzionalizmust erősítik és azt az élményt jelentik a munkavállalónak, hogy közösen, közös szakmai alapokon, egy folyamatos figyelem mellett, fontos munkát végeznek. A kisgyermeknevelők jelezték a visszajelzésekkel kapcsolatos hiányérzetüket: „A kisgyermeknevelők fejlődéséhez nagyon fontos lenne a pozitiv megerösités, hogy jól csinálja a munkáját, hogy szükség van rá, ez motiválja az embert.; „Sokkal több visszajelzést várnék a felsőbb vezetöségtöl a munkámmal kapcsolatosan." Szükségük van támpontokra és arra, hogy azt érezzék, fontos, amit és ahogyan tesznek nap, mint nap.

A családoktól érkező visszajelzések nem garantáltak, habitus, egyedi, egyéni kommunikációs lehetőségek függvénye, van, aki tud, akar visszaje- 
lezni, de nem egyöntetű és nem biztos, hogy olyan módon történik, ami a kisgyermeknevelő számára konkrét szakmai támpontokat adna. Inkább globális, pozitív jelzésekként érkeznek. A korábbi években az intézményünkben folytatott szülői elégedettségi kérdőívekben a szülői visszajelzések már pontosabb és összemérhető dimenziókról adtak képet a kisgyermeknevelők számára, de nem személyre szólóan. A visszajelző kérdőívek eredményeinek értelmezése szakmai lehetőséget teremt a konklúziók levonására. Ezt az alkalmat a vezetőnek szintén érdemes megteremtenie.

A szakmai személyiség támogatásának másik fontos lehetősége a csoportos formában történő közös „szakmázás”. A jól müködő bölcsődei csoportok általában megteremtik maguk számára a rendszeres megbeszéléseket, de minden kisgyermeknevelő számára fontos lenne a rendszeres, strukturált esetmegbeszélés, közös gondolkodás. A kisgyermeknevelők egy viszonylag szűk felnőtt körrel töltik a napjaikat, leginkább két, három felnőtt működik szorosan együtt a napi munka során. Igen érzékeny területe a szakmai életüknek ez a szoros kötelék. A gyermekekkel zajló gondozás és nevelés során a figyelem, a jelenlét, a kommunikáció leginkább számukra van fenntartva és elengedhetetlen ennek a kiegyensúlyozott, állandó minősége. A felnőttek együttműködése nem vehet ebből el. Ezért a kisgyermeknevelők számára kiemelten fontos az együtt dolgozó párok, csoportbeli munkatársak között a harmonikus munkakapcsolat: „Tényleg nagyon fontos, hogy egy nagyon jó társad legyen, akivel megértitek egymást." Ennek a megteremtéséhez egymás megismerésén, a rendszeres kommunikáción át vezet az út. A tágabb bölcsődei munkatársi környezet, az egy intézményben dolgozó kisgyermeknevelők kapcsolódásai szintén sokat adnak a szervezeti identitás kiépüléséhez és a tudásmegosztáshoz, tanuláshoz, fejlődéshez. Kirajzolódott az is, hogy a kisgyermeknevelőknek erre igénye van, és a vezető teremtheti meg ennek lehetőségeit, illetve a szakmai megbeszélőcsoportok, esetmegbeszélések adhatnak hozzá megfelelő keretet. A kisgyermeknevelőknek a saját hivatástudatuk, szakmai ismereteik, határaik és lehetőségeik ismerete, tudatosítása azért fontos, hogy magabiztos, egyenrangú félként lehessenek partnerei a szülőknek gyermekük nevelése során.

A kisgyermeknevelők az interjúk során rendszeresen kiemelték a jó munkahelyi közösség fontosságát: „Ami itt tart, az még a közösség, ami kialakult a munkahelyemen.;; A kollégákkal való kapcsolat nagyon fontos, hogy olyan közegbe kerüljek, ahol jól érzem magamat.”; „A kollégákkal való kapcsolat nagyon fontos, és jó velük együtt dolgozni."; „Nagyon fontos, hogy az ember megtalálja azt a helyet, azt a bölcsődét, ahol jól érzi magát." Ez azt jelenti, hogy a napi munka során történő együttműködés minősége, élménye, hangulata nagyban befolyásolja a gyermekekkel végzett minőségi munkát és a motivációt, a szakmai közérzetet és a hosszú távú szakmai terveket. A kisgyermeknevelők véleménye alapján a jó bölcsődei közösség a vezető által teremtődhet meg. A vezető munkatársakhoz való viszonyán keresztül tudja a szakmai munkát megfelelően támogatni. A vezetők aktív jelenlétét, megszólíthatósá- 
gát, támogatását, nyitottságát és szakmai tudását a kisgyermeknevelők a saját szervezeti közérzetük alapvető pilléreként említették: „A bölcsődevezető ne főnök legyen, hanem vezető, mert ha azt jól csinálja, akkor az mindenkinek jó, az a kulcsa, hogy tudja magával vinni az embereket." A szakemberek felé irányuló kommunikáció tisztasága, nyíltsága, közvetlensége egy folyamatos jelenléttel párosulva a szervezet iránti bizalmat, a megtartottságot hívja életre. A vezetők időben megfelelő és minőségi reakciói eseményekre, történésekre, valamint lojalitása a munkatársai iránt nagymértékben erősítik a kisgyermeknevelők biztonságérzetét és a munkamotivációját.

Az interjúkból kirajzolódott, hogy mennyire fontos és meghatározó, hogy a pályakezdő pedagógus elfogadó, támogató, tapasztalt kisgyermeknevelő mellé kerüljön: „Nagyon jó csoportba kerültem, az én kolléganöm egy közel negyvenéves tapasztalt kisgyermeknevelö volt, aki nagyon sokat segitett nekem abban, hogy megtaláljam a helyemet a csoportban. Hagyott engem kibontakozni, de közben segitett, hogy önállóan is el tudjam végezni a feladatokat. Nem azt éreztem, hogy ő a fönök, hogy szó szerint követnem kell, hagyta, hogy rájöjjek a dolgokra.”; „Nagyon meghatározó és nagyon fontos, hogy kinél kezd a pályakezdö, erre nagyon oda kellene figyelni. Volt pályakezdö, aki azért ment el, mert nem jó személynél kezdett.”; „Biztonságot adott, hogy olyan kolléganőhöz kerültem, aki tapasztalt volt."

A kisgyermeknevelők számára is alapvető, hogy megfelelő munkakörülmények között és tárgyi feltételek mellett dolgozzanak, ezek a tényezők szintén befolyásolják a szakmai közérzetüket: „Fontos a környezet, hogy a bölcsőde is olyan legyen, ahol az ember szivesen dolgozik.”; "Ami engem elijesztene, az a rossz munkakörülmények, és ha nem lenne semmi újdonság, nem lenne oktatás, akkor belefásulna az ember."

A társadalmi megbecsültség érzésének hiánya, mint a szakmai közérzetüknek meghatározó eleme szinte minden adatközlőnél felmerült: „Még mindig társadalmi szinten nem vagyunk megbecsülve, pedig állítom, hogy itt folyik a legnagyobb munka, itt van a megalapozás. A régmúlt gyermekmegörzö jelleg az ott leragadt, és nincs visszhangja, hogy mennyit fejlödött a bölcsöde.; „A köztudatban sem vagyunk benne, ez egy nehéz munka fizikailag és lelkileg is.”; „A kisgyermeknevelö szakma nincs elismerve, mintha nem is létezne, pedig ez a legmeghatározóbb korosztály."

A szülőktől (bölcsődei) jövő megnyilvánulások, megszólítások azt a képet mutatják, hogy nincs körvonalazott elképzelésük se a kisgyermeknevelők képzettségét se a feladataik összetettségét tekintve: „Elismerés az, amire mindenki vágyik, aki ebben a szakmában dolgozik. Alapdolog, hogy ismerjenek el, a társadalom is. Ebben benne van az is, hogy a szülök ne szólitsanak dajkának, dadusnak.”; "Volt olyan szülö, aki, amikor meghallotta, hogy föiskolán végeztem, akkor teljesen megkönnyebbült, hogy milyen szakképzett emberek vigyáznak az ő gyerekeire. Van mögötte egy tudás.”; „A szülök nagy része nem tudja, hogy mit csinálunk a csoportban, mennyit tanulnak a kisgyermeknevelök." A kisgyermeknevelő megnevezés is csak a bölcsőde irányából érkezik, egyébként 
a köztudatban gondozónő, dadus, dada, dajka - néven ismert, ennek a dajkáló, gondozó jelentéseit kifejezve. A gyermekek beszoktatási időszakában a szülők elvileg belelátnak a gondozó-nevelő munkába, mégsem tudják, mi is történik a nap során. Hiszen nem erre figyelnek. Nem kapnak erről kiemelten tájékoztatást, csak azzal kapcsolatban, ami az ő szülői együttműködésüket is érinti.

Az interjúkban az anyagi megbecsülés fontossága is felbukkant: „Negatívum a fizetés, és hogy nem vagyunk megbecsülve.”; „Fontos a megélhetö fizetés.”; „Ha elhagynám a pályát, az a fizetés miatt lenne, nem lehet belóle megélni."

\section{A kisgyermeknevelök szakmai jövöképe}

A megkérdezett diplomás kisgyermeknevelők nem tekintik végállomásnak és végcélnak jelenlegi munkájukat. Kivétel nélkül mindannyian konkrét továbbtanulási, tanulási és jó néhányan konkrét szakmai jövőképpel is rendelkeznek. (8. ábra)

8. ábra

Kisgyermeknevelök szakmai jövöképe

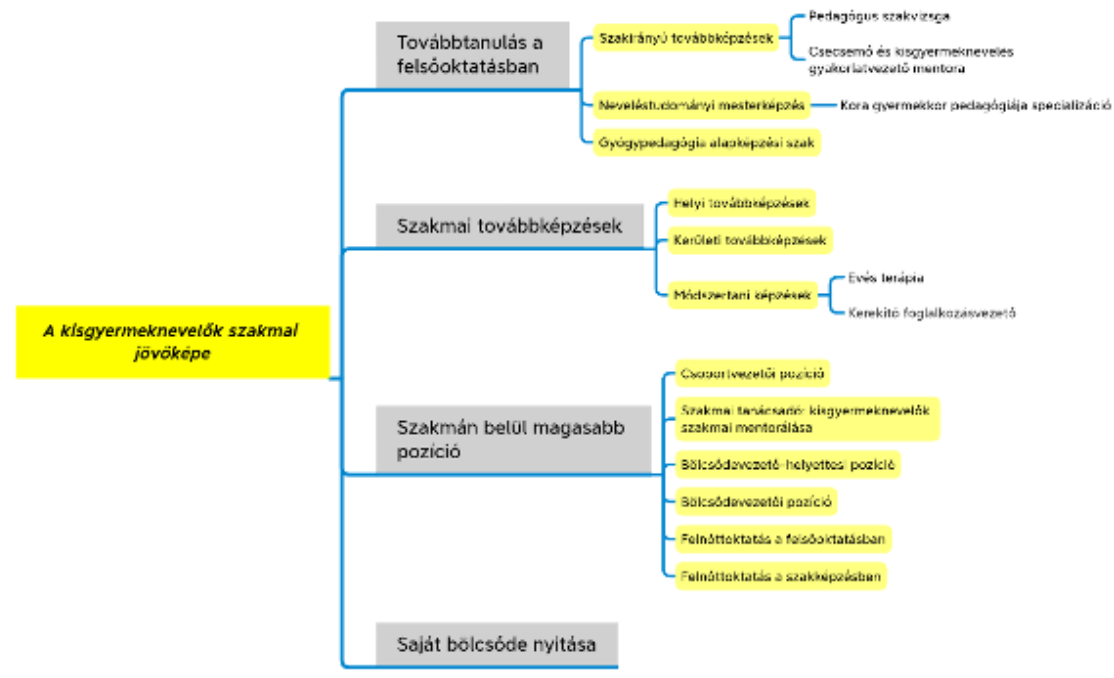

A továbbtanulás iránya a saját érdeklődésekhez vagy a távolabbi célokhoz rendelhető ismeretek megszerzéséhez kapcsolható. Egyöntetűnek mondható, hogy a csoportban való munka hosszú távon nem jelent valódi perspektívát, de maga a „bölcsőde tudománya” és a bölcsőde világa elég érdekes, gazdag és fontos számukra, nem szeretnék felcserélni valami másra: „Szeretnék még tanulni, de kizárólag a szakmán belül.”; „Mindenképpen szeretnék valamit tanulni, ami a gyerekekkel kapcsolatos." A diplomás fiatalok látnak 
perspektívákat a „bölcsődében”. A BA-képzésen látogatott gyakorlati órák élményei többük számára meghatározóak voltak, találkozhattak olyan tapasztalt kollégákkal, akik jól támogatták őket a kezdeti lépésekben vagy éppen arra láttak rá, mi hiányzott számukra.

A mentorálás, a fiatalok segítése a pályán, a szakmában való eligazítás az egyik irány, ami a szakmai jövőképek között megjelenik: „Én is szeretnék mentori képzést csinálni, hogy én is lehessek a hallgatóknak a szakmai mentora a bölcsődében.”; „Szeretnék többet tanulni, egy olyan személy szeretnék lenni, aki segíti a leendö kisgyermeknevelöket, akár egy mentor is lennék."; „Szeretném magamat képezni, a mentorképzés is érdekel."

A kisgyermeknevelők csoportvezetői, bölcsődevezetői és oktatói aspirációi szintén jelen vannak az elképzelések között: „Szivesen lennék csoportban csoportvezetö, ez ad egy nagyobb felelösséget. Erre nekem szükségem lenne"; „A pedagógusoktatásba több olyan szakember kellene, akik maguk tapasztalták meg a csoportban a dolgokat. Tehát vezetöi vagy oktatói munkakörben képzelném el magamat.; "Szeretnék bölcsödevezetöi képzést is elvégezni, mert szeretném majd késóbb kipróbálni magamat vezetöi szerepben is."

A kisgyermeknevelők szinte mindig kiemelték a vezetővel való jó, termékeny kapcsolatukat, akik példát és szakmai segítséget jelentenek a mindennapokban számukra. Ezek a pozitív, inspiráló példák alapjául szolgálnak a megkérdezett kisgyermeknevelök távolabbi terveinek.

A megkérdezett diplomás kisgyermeknevelők megfelelően tájékozottak a jelenlegi képzési repertoárt és a továbbhaladás lehetőségeit illetően, ez köszönhető a felsőoktatásban való aktív részvételnek, ahol az információk jóval közelebb vannak a hallgatókhoz. A diplomás kisgyermeknevelők rá is éreznek az ebben rejlő lehetőségekre, a korábbi oktatásban megélt sikereik és a szakmai beválásuk, a pályaválasztásuk sikere a tanulás, a változás, a fejlődés irányába elkötelezetté teszi őket. A felsőoktatásban való továbbtanulás (szakirányú továbbképzések, neveléstudományi mesterképzés és a gyógypedagógia alapképzési szak), valamint a szakmai továbbképzések (helyi és kerületi továbbképzések, valamint módszertani képzések) megjelennek a kisgyermeknevelők tanulási tervei között. Elmondásuk szerint a vizsgázással, tanulással járó nehézségek sem jelentenek akadályt számukra.

A kisgyermeknevelők szakmai kiteljesedésének csúcsa egy saját bölcsőde „megalkotása” lehet: „Szeretnék egy magánbölcsődét nyitni később, fontos feljebb lépni a ranglétrán, ehhez viszont tudásra van szükség."

\section{Konklúzió}

Összességében, azon túl, hogy a diploma megszerzésével egy komoly cél teljesült, a BA-képzés elvégzésének a megkérdezett kisgyermeknevelők által a jelenben megragadható hozadéka az élethosszig való tanulás iránti elkötelezettség kialakulása, az önbecsülés érzése, a jövőbeni célok realizálásának lehetősége vagy az oda vezető út önálló, tudatos megteremtésének biztonsága. 
A BA-t végzett kisgyermeknevelők magabiztosak az elméleti és gyakorlati ismereteiket illetően és azzal kapcsolatban is, milyen lehetőségeik vannak a további szakmai útjukon.

Minden kisgyermeknevelöre igaz, hogy nem „tartható” csak a csoportszobában, mint egy el nem fogyó lelkesedés. Ki kell „engedni” olyan terepekre, ahol új nézőpontokat, módszereket, szemléleteket ismerhet meg. Ahol a tanuló énje újra és újra aktívvá tud válni. Ez teremti meg a lehetőséget arra is, hogy a saját munkájára, esetleg rutinszerűen végzett feladatokra, napi működésre távolabbról rátekinthessen, hogy azok életre keljenek, megújuljanak. Ahhoz, hogy a saját, már meglévő kompetenciáit, ismereteit tudatosan alkalmazza, meg kell „forgatnia” az új ismeretekben.

A bölcsőde diszkréten teszi a dolgát. Pedig tehetné akár büszkén, transzparensen is. A bölcsődében dolgozó szakemberek tapasztalatai, ismeretei fontos és hasznos ajándékok a kisgyermeket nevelő családok számára. Ahhoz, hogy részesülhessenek a bölcsődékben felhalmozott tudásokból, a kisgyermeknevelőknek megfelelő szakmai önbizalommal és kompetencia élménnyel kell végezniük a munkájukat, ami szoros összefüggésben van a családokkal való együttmüködés és társadalmi megítélés milyenségével. A családok, a szülők keveset tudnak a bölcsődéről, előfeltételezésekre, a társadalom által jelenleg közvetített belső képekre vagy megérzésekre támaszkodnak. A bölcsődében folyó munkának, a gondozási és nevelési feladatok mibenlétének, a szakértelem mögötti képzési folyamatoknak és azok tartalmainak megismertetésevel a szülők és a kisgyermeknevelők közötti kapcsolat más alapokról építkezne. A közös „tudás” szükségtelenné tenné a bölcsődei kisgyermeknevelők társadalmi megítélés következtében kialakult rossz érzéseit, ami a szakmai identitásukra is hatással lehet. A megfelelő tájékoztatáson alapuló társadalmilag megelőlegezett bizalom kiépítése szakpolitikai kérdés és nem kizárólag a bölcsőde feladata, de sokat tehet érte. Csak a szaktudásában és a szakmai személyiségében folyamatosan gondozott, támogatott szakemberi kör tud annak a képnek megfelelni, amit mi, a bölcsődékben hivatásukat gyakorlók, szeretnénk látni, láttatni önmagunkkal kapcsolatban.

Úgy gondoljuk, hogy csak a magasan képzett, szakmai személyiségében folyamatosan gondozott, képzésekkel, önismereti munkával támogatott és társadalmi szinten elismert, megismert bölcsődei kisgyermeknevelők tudják a kora gyermekkor kiemelten fontos korszakát a családokkal partneri együttmüködésben jól támogatni.

\section{Zárszó}

Kutatásunk nem zárult le a csecsemő- és kisgyermeknevelő BA-végzettséggel rendelkező kisgyermeknevelők szakmai közérzetének és jövőképének megismerésével. Kutatásunk az OKJ-s végzettséggel rendelkező kisgyermeknevelők szakmai közérzetének és jövőképének a feltárásával folytatódik. Jelen kutatás segítséget jelent a két csoportot célzó összehasonlító elemzésben. 


\section{Irodalom}

6/2016. (III. 24.) EMMI rendelet a személyes gondoskodást nyújtó gyermekjóléti, gyermekvédelmi intézmények, valamint személyek szakmai feladatairól és müködésük feltételeiröl szóló 15/1998. (IV. 30.) NM rendelet módositásáról

Dén-Nagy, I, Géring, Zs., Király, G. \& Nagy, B. (2014). Kevert módszertanok alkalmazása a munka- magánélet egyensúly kutatásában. Kultúra és Közösség, 5(3), 149-158. Corvinus kutatások. http://unipub.lib.uni-corvinus.hu/1892/ (2021.02. 04.)

Király, G., Dén-Nagy I., Géring, Zs. \& Nagy, B. (2014). Kevert módszertani megközelítések. Elméleti és módszertani alapok. Kultúra és Közösség, 5(2), 95104. Corvinus kutatások. http://unipub.lib.uni-corvinus.hu/1895/ (2021. 02. 04.)

Kucsera, Cs. (2008). Megalapozott elmélet: egy módszertan fejlódéstörténete. Szociológiai Szemle, (3) 92-108. Magyar Szociológiai Társaság. https:// szociologia.hu/dynamic/SzocSzemle_2008_3_092_108_KucsereCs.pdf (2021.02.17.)

Mitev, A. Z. (2012). Grounded theory, a kvalitatív kutatás klasszikus mérföldköve. Vezetéstudomány, 43(1), 17-30. https://doi.org/10.14267/VEZTUD.2012.01.02

Mitev, A. (2015). Elméletalkotó technika - A kutató elméletet fejleszt. Grounded Theory. In Horváth, D. \& Mitev, A. (Eds.), Alternatív kvalitatív kutatási kézikönyv (pp. 85-126.). Alinea Kiadó.

Podráczky, J. (2020). A csecsemő- és kisgyermeknevelő képzés a pedagógusképzés rendszerében - az első 10 év mérlege. Gyermeknevelés Tudományos Folyóirat, 8(1), 5-14. https://doi.org/10.31074/gyntf.2020.1.5.14

Sallay, V. \& Martos, T. (2018). A grounded theory (GT) módszertana. Magyar Pszichológiai Szemle, 73(1/2), 11-28. https://doi.org/10.1556/0016.2018.73.1.2

Sántha, K. (2012). Numerikus problémák a kvalitatív megbízhatósági mutatók meghatározásánál. Iskolakultúra, 22(3), 64-73. http://www.iskolakultura.hu/ index.php/iskolakultura/article/view/21248 (2021. 02. 17.)

Sántha, K. (2020). Abdukció a kvalitatív tartalomelemzésben. Neveléstudomány, Oktatás - Kutatás - Innováció, 8(2), 26-36. https://doi.org/10.21549/NTNY.29.2020.2.2 


\section{Bencsikné Molnár, R. \& Orbán, D.}

\section{Professional well-being and vision of graduate early-childhood educators}

The present study concerns the professional well-being of graduate early-childhood educators and attempts to interpret the perspectives of early childhood educators in relation to their professional future. For this, it was essential to get to know their professional way of life, looking at the motives of career choice, the experiences of infant and early-childhood education training, as well as the working conditions of the nursery institutions. Our research includes 15 graduate early-childhood educators working in Ujbuda Nursery Institutions, 10 of whom are also OKJ-qualified. The unexpected result of our research was that light was also shed on the distinctive features of the two levels of training. In our research we combined the individual written interviewing and the semi-structured interview. The semi-structured interviews were analyzed using Atlas.ti content analysis software, which is based on grounded theory. Our analysis follows the principles of this method, the analysis of the data - the inductive categorization - is based on the analysis strategy of Glaser (1992). The results point to the conditions that can keep early childhood educators motivated and happy in the long run in their pedagogical career, ensuring healthy professional well-being. a high professional calling is reflected in the fact that all of the early-childhood educators interviewed who work in our institution have continuing education training, some with a specific professional outlook related to the profession. Our results may provide not only important knowledge of the nursery specialty and the professionals working in its development, but the variety within the infant and early-childhood profession also offers highlights for parents.

Keywords: nursery, professional well-being of early-childhood educators, vision, grounded theory, qualitative content analysis

Bencsikné Molnár Réka: https://orcid.org/0000-0002-1758-6816 